JOEAI (Journal of Education and Instruction)

Volume 2, Nomor 1, Juni 2019

e-ISSN : 2614-8617

p-ISSN : 2620-7346

DOI : https://doi.org/10.31539/joeai.v2i1.584

IMgEKpe

\title{
SIKAP GURU TERHADAP ANAK BERKEBUTUHAN KHUSUS DI SEKOLAH INKLUSI
}

\author{
Khusna Yulinda Udhiyanasari \\ IKIP PGRI JEMBER \\ Khusnayulinda37@gmail.com
}

\begin{abstract}
ABSTRAK
Penelitian ini bertujuan untuk mengetahui bagaimana karakteristik ABK secara umum, bagaimana peranan sekolah inklusi bagi para ABK, bagaimana sikap guru dan ABK di sekolah inklusi dan bagaimana sikap guru terhadap ABK di sekolah inklusi. Metode penelitian menggunakan metode deskriptif dengan menganalisa karakteristik ABK secara umum, peranan sekolah inklusi bagi para $A B K$, sikap guru dan $A B K$ di sekolah inklusi dan sikap guru terhadap ABK di sekolah inklusi. Hasil penelitian menunjukkan bahwa sikap guru disekolah inklusi (SD Kebonsari 5, Jember) memiliki sikap yang kurang baik terhadap ABK. Hasil ini diperoleh dari sikap guru yang kurang respek terhadap penanganan ABK dan juga dapat diketahui dari analisis pada narasumber yaitu salah satu siswa kelas 1 SD yang berusia 10 tahun (TM). Simpulan, berdasarkan temuan penelitian maka sebaiknya guru di sekolah inklusi diharapkan dapat meningkatkan kemampuan dalam menangani ABK melalui pelatihan-pelatihan yang diselenggarakan oleh pemerintah, komite sekolah dapat mengoptimalkan peranan sekolah inklusi bagi ABK, pihak-pihak yang terkait ikut serta dalam membantu peran pemerintah dalam meningkatkan kemampuan dan pemahaman guru tentang pendidikan inklusi sangat diperlukan agar tujuan dari pendidikan inklusi yaitu memberikan pendidikan yang sama dan merata kepada ABK dapat berjalan dengan baik.
\end{abstract}

Kata Kunci : Sikap Guru, Sekolah Inklusi, Anak Berkebutuhan Khusus.

\section{ABSTRACT}

This study aims to find out how the characteristics of $A B K$ in general, how the role of inclusive schools for $A B K s$, how the attitudes of teachers and $A B K$ in inclusive schools and how the attitudes of teachers towards $A B K$ in inclusive schools. The research method used a descriptive method by analyzing the characteristics of $A B K$ in general, the role of inclusion schools for $A B K$, the attitudes of teachers and $A B K$ in inclusive schools and the attitudes of teachers towards $A B K$ in inclusive schools. The results showed that the attitudes of inclusive school teachers (SD Kebonsari 5, Jember) had a bad attitude towards ABK. This result is obtained from the teacher's attitude that lacks respect for the handling of $A B K$ and can also be known from the analysis of the resource person, one of the 10-year-old elementary school students (TM). Conclusion, based on the research findings, it is better if teachers in inclusive 
schools are expected to be able to improve their ability to handle ABK through trainings organized by the government, school committees can optimize the role of inclusive schools for $A B K$, related parties participate in assisting the government's role in improving The teacher's ability and understanding of inclusive education is very much needed so that the goal of inclusive education, which is to provide equal and equitable education to ABK, can run well.

Keywords: Teacher Attitudes, Inclusion Schools, Children with Special Needs.

\section{PENDAHULUAN}

Pendidikan merupakan kebutuhan dasar setiap manusia untuk menjamin keberlangsungan hidupnya agar lebih bermartabat. Karena itu negara memiliki kewajiban untuk memberikan pelayanan pendidikan yang bermutu kepada setiap warganya tanpa terkecuali termasuk mereka yang memiliki perbedaan dalam kemampuan (difabel).

Pendidikan inklusi merupakan perkembangan terkini dari model pendidikan bagi anak berkelainan secara formal. Prinsip mendasar dari pendidikan inklusi adalah selama memungkinkan, semua anak seyogyanya belajar bersama-sama tanpa memandang kesulitan ataupun perbedaan yang mungkin ada pada mereka. Hal ini akan membuat mental pada anak-anak berkebutuhan khusus semakin membaik dan bisa dengan mudah dalam melakukan penyesuaian terhadap situasi kelas atau sekolah secara umum.

Pendidikan yang baik seharusnya memiliki prioritas untuk mengembangkan potensi, bakat dan minat yang dimiliki peserta didik. Sehingga peserta didik dapat berprestasi dalam hal selain akademik. Pada dasarnya memasukkan anak berkebutuhan khusus kedalam sekolah inklusis (sekolah anak-anak normal) merupakan hal yang sangat membahagiakan bagi orangtua anak berkebutuhan khusus. Harapan orangtua terhadap sekolah inklusi sangatlah besar untuk dapat merubah dan memperbaiki kondisi psikis, akademik dan sosialisasi anak berkebutuhan khusus.

Sayangnya, pendidikan inklusi yang sudah mulai banyak diterapkan disekolah-sekolah umum kurang berjalan sesuai harapan. SD inklusi yang telah menerima anak-anak dengan berkebutuhan khusus tidak langsung menangani anak berkebutuhan khusus tersebut. Kurikulum harus dapat disesuaikan dengan kelas yang heterogen dengan karakteristik ABK dan regular. Guru belum siap untuk menangani anak-anak dikelasnya dengan karakteristik yang berbeda. Akhirnya, guru-guru yang berhadapan langsung dengan ABK di kelas mengeluh dan sulit untuk mengajar satu metode yang sama dan dengan perlakuan yang sama sehingga tujuan pembelajaran tidak tercapai seperti yang diharapkan. Pengembangan kurikulum dapat dilakukan 
sebagai upaya menciptakan pembelajaran yang menyenangkan dan tujuan pembelajaran dapat tercapai dalam pendidikan inklusi.

Pendidikan inklusi di SD belum beriiringan dengan visi pendidikan belum berdasarkan inklusi ethos yang mengedepankan keragaman dan kesamaan hak dalam memperoleh pedidikan. Kurikulum dan metode pengajaran yang kaku dan sulit diakses oleh ABK masih ditemukan pada kelas inklusi. Pengintergrasian kurikulum belum dapat dilakukan oleh guru Karena kemampuan guru yang terbatas. Guru-guru belum mendapatkan training yang praktikal dan kebanyakan yang diberikan sifatnya hanya sebatas sosialisasi saja. Wali kelas dan atau guru bidang studi yang kedapatan dikelasnya ada ABK masih menunjukkan sikap "terpaksa" dalam mendampingi ABK memahami materi. Guru umum yang ada di sekolah inklusi memiliki tantangan yang berbeda dengan guru yang mengajar "anak normal". Terkait guru kelas di sekolah inklusif, Leskey (2013) berpendapat bahwa Guru kelas umum dituntut untuk memiliki pengetahuan terkait kurikulum dan rancangan pembelajaran sesuai dengan karakteristik anak berkebutuhan khusus tersebut. Dengan demikian guru harus memahami pula karakteristik serta kelebihan dan kekurangan yang dimiliki anak berkebutuhan khusus.

Faktor-faktor yang dapat mempengaruhi Sikap penerimaan guru terhadap pendidikan inklusi yaitu : Berdasarkan tingkat pendidikan guru, guru yang memiliki tingkat pendidikan tinggi dan sesuai dengan bidangnya akan menunjukkan sikap yang berbeda dengan yang memiliki tingkat pendidikan lebih rendah. Sebagai contoh jika guru berpendidikan S1 dengan lulusan pendidikan luarbiasa, akan berbeda sikapnya dengan guru S1 dengan lulusan PGSD. Begitu pula dengan pendidikan setara D3 atau S2 dan S3. Latar belakang dan tingkat pendidikan memiliki peran terhadap sikap penerimaan guru dikarenakan guru akan benar-benar paham hakekat dari anak berkebutuhan khusus, pendidikan anak berkebutuhan khusus serta penanganan yang tepat. Pemahaman akan ketidakmampuan anak berkebutuhan khusus saat proses pembelajaran sudah dipahami sejak awal, sehingga tuntutan guru terhadap anak berkebutuhan khusus tidaklah besar melainkan lebih kepada konsep pemahaman bukan konsep yang dilihat dari nilai.

Efikasi diri adalah keyakinan individu mengenai kemampuan dirinya dalam melakukan tugas atau tindakan yang diperlukan untuk mencapai hasil tertentu. Guru dengan efikasi diri yang rendah menghadapi lebih banyak masalah dalam implementasi pendidikan inklusif. Keyakinan yang dimiliki oleh seorang guru terhadap apa yang akan dilakukan pada saat pelaksanaan pendidikan inklusi dapat memberikan efek yang positif atau juga negative. Jika seorang guru sudah memiliki ketidakyakinan pada diri sendiri dalam menghadapi anak berkebutuhan khusus dalam sekolah inklusi akan berpengaruh terhadap kinerja yang dilakukan dalam proses belajar mengajar. 
Dalam proses pembelajaran sering kita dengar dengan sebutan guru senior, label tersebut diberikan kepada guru yang sudah lama dalam mengajar dan memiliki pengalaman yang sangat banyak dalam hal pengajaran. Guru dengan jam terbang yang tinggi atau kita sering sebut guru yang berpengalaman akan cenderung memiliki kemampuan yang lebih tenang, dan mempunyai banyak solusi dalam proses belajar dikelas dengan anak berkebutuhan khusus. Berbeda halnya dengan guru yang tidak memiliki pengalaman mengajar, dalam proses pembelajaraan akan cenderung mudah gelisah, dan sulit memperoleh solusi dalam permasalahan ketika mengajar. Tetapi hal ini akan sangat mudah dikondisikan apabila guru selalu mau belajar dan menerapkan secara langsung apa yang telah dipelajari dengan diimplementasikan langsung kepada anak berkebutuhan khusus, memiliki jam terbang yang tinggi, maka semua permasalahan dalam proses belajar akan mudah diselesaikan.

Dunia pendidikan saat ini sangat mendukung untuk para guru meningkatkan kualitas diri (perform) untuk meningkatkan kualitas dalam proses penmbelajaran disekolah. Guru yang sering melakukan pelatihan akan memiliki pandangan yang lebih positif terhadap anak berkebutuhan khusus. Pelatihan dimaksudkan untuk lebih membuka wawasan tentang pentingnya pendidikan terhadap anak berkebutuhan khusus, karakter pendidikan yang baik bagi anak berkebutuhan khusus, yang lebih penting adalah sikap guru dalam hal menangani anak berkebutuhan khusus. Dengan adanya pelatihan yang sering diikuti guru, guru memiliki skor yang lebih tinggi pada komponen kognitif-afektif dan komponen perilaku.

Dalam hal ini yang dimaksud diferensiasi peserta didik adalah seberapa besar tingkat ketidakmampuan peserta didik. Anak-anak dengan disabilitas berat memiliki tingkat kesulitan yang lebih tinggi juga dalam penanganan didalam proses pembelajaran. Hal ini akan membuat sikap guru menjadi kurang positif. Sehingga tingkat ketidakmampuan anak berkebutuhan khusus yang akan disekolahkan di sekolah inklusi perlu dipertimbangkan. Guru akan mengalami kesulitan jika guru tersebut tidak memahami secara mendetail karakter, problem, dan cara penanganan anak berkebutuhan khusus. Penanganan anak dengan disabilitas rendah harus memiliki banyak strategi dan metode dalam proses pembelajaran. Guru dituntut untuk kreatif dalam proses belajar agar anak mudah memahami apa yang sedang disampaikan oleh guru saat belajar mengajar

Proses pembelajaran dalam konsep inklusi sebaiknya guru pahami dengan lebih baik, sehingga didalam penerapannya dapat secara maksimal. Anak berkebutuhan khusus diberikan pelayanan sesuai dengan kebutuhannya. Beberapa kriteria sekolah yang sudah siap dalam menerapkan proses pembelajaran adalah sebagai berikut : 1) dalam sekolah inklusi seharusnya memiliki kelebihan pada tenaga pengajar. Per kelas sebaiknya ada 2 sampai 3 pengajar. Tujuannya adalah ketika ada anak yang rewel, sudah siap di handle. Jadi kelas tetap bisa kondusif. Anak yang 
rewel pun di beri pengajaran khusus agar tetap bisa mengikuti pelajaran sehingga tidak tertinggal dengan teman-temannya yang lain. Pembelajaran dikelas menjadi lebih kondusif, 2) banyaknya guru pendamping khusus, guru pendamping khusus atau yang sering disebut GPK sebenarnya sangatlah penting ketika anak bersekolah disekolah inklusi. Karena dengan adanya guru pendamping khusus, anak berkebutuhan khusus lebih mendapatkan perhatian dan pendampingan secara menyeluruh. Satu guru pendamping bertanggungjawab terhadap satu anak berkebutuhan khusus. Untuk menilai suatu progress atau peningkatan dalam belajar anak lebih mudah karena guru pendamping benar-benar memahami kemampuan awal anak sampai dengan kemampuannya sekarang. Melakukan pertanggungjawaban ke orangtua anak juga lebih mudah, 3) ketersediaan fasilitas untuk anak berkebutuhan khusus, beberapa anak berkebutuhan khusus membutuhkan fasilitas pendukung dalam proses pembelajarannya disekolah, fasilitas -fasilitas tersebut sebaiknya sudah siap sebelum anak berkebutuhan khusus siap belajar, agar tidak mengganggu dalam proses belajar siswa. Banyak yang perlu dipersiapkan ketika anak akan masuk ke dalam sekolah inklusi salah satunya adalah sarana dan prasarana pendukung dalam proses belajar anak disekolah, 4) kewajiban dalam mengikuti kelas umum, semua anak berkebutuhan khusus harus mengikuti pelajaran dengan anak-anak normal tanpa terkecuali, walaupun kemampuannya tidak mampu untuk mengikuti.

Hal ini dikarenakan anak berkebutuhan khusus tidak hanya dalam hal akademik, tetapi dalam hal sosialisasi, interaksi dengan teman-teman sangatlah penting. Untuk akademik bisa dilakukan remedial di luar jam belajar bersama anakanak normal lainnya, 5) pemberian pelajaran moral, selain pelajaran akademik, anak juga di edukasi oleh beberapa pendidikan lain. Salah satunya adalah pendidikan moral. Jadi mereka di beri pengertian tentang pelecehan seksual itu seperti apa. Cara identifikasi bagaimana, dan jika ia mendapat pelecahan apa yang harus dilakukan. Kemudian, anak juga diberikan pengertian tentang bullying. Sehingga bisa mengatasi ketika berada di lingkungannya nanti. Sebab anak ABK memang sangat rentan di bully oleh anak - anak lain. Menurut Mustofa (2017) dalam penelitiannya yang berjudul Sikap guru kelas terhadap anak berkebutuhan khusus disekolah inklusi menyatakan bahwa Sikap guru kelas terhadap anak berkebutuhan khusus secara konsisten memiliki sikap kategori sangat buruk. Dengan demikian dapat diurai bahwa terdapat guru kelas yang memiliki pemahaman terkait anak berkebutuhan khusus dengan kategori sangat buruk. Pemahaman yang buruk tersebut juga ditunjukan dengan rendahnya perasaan peduli terkait anak berkebutuhan khusus. Sehingga kecenderungan perilaku guru yang muncul berkaitan dengan anak berkebutuhan khusus juga menunjukkan kategori buruk. Hal ini membuktikan bahwa rendahnya pemahaman guru terhadap anak berkebutuhan khusus didunia pendidikan inklusi. Penelitian ini bertujuan untuk mengetahui bagaimana karakteristik ABK secara 
umum, bagaimana peranan sekolah inklusi bagi para ABK, bagaimana sikap guru dan ABK di sekolah inklusi dan bagaimana sikap guru terhadap ABK di sekolah inklusi.

\section{METODE PENELITIAN}

Bentuk penelitian ini adalah penelitian kualitatif, karena dalam hal ini peneliti mengolah data dan menganalisis suatu masalah secara non numerik. Arikunto (2002) mengatakan bahwa dari sekian banyak model dalam penelitian kualitatif yang dikenal di Indonesia adalah penelitian naturalistic atau penelitian natural. Istilah natural menunjukkan bahwa penelitian ini dilaksanakan apa adanya dalam situasi normal yang tidak dimanipulasi keadaan dan kondisinya menekankan pada diskripsi secara alami.

Penelitian ini menggunakan metode deskriptif dengan menganalisa dampak dari sikap penerimaan guru terhadap anak berkebutuhan khusus di sekolah inklusi. Sikap penerimaan yang positif akan berdampak pada kondisi anak berkebutuhan khusus meliputi kondisi psikis, akademis dan sosial yang lebih baik pada anak berkebutuhan khusus. Dalam penelitian ini peneliti mengambil subyek penelitian

yaitu salah satu peserta didik disekolah inklusi yang memiliki hambatan dalam psikis, akademik dan sosial.

Penelitian ini bermaksud untuk memberikan gambaran yang positif terhadap masyarakat terutama guru khususnya dalam memperkaya berfikir bahwasanya tidak ada yang sempurna. Setiap individu memiliki kelebihan dan kekurangan. Sehingga peran guru dalam hal ini adalah menggali kelebihan anak-anak berkebutuhan khusus yang bersekolah di sekolah inklusi agar dapat bersaing secara sehat dengan anak-anak normal lainnya.

\section{HASIL DAN PEMBAHASAN}

Hasil penelitian menunjukkan bahwa sikap yang ditunjukkan oleh guru disekolah inklusi terhadap anak anak berkebutuhan khusus yang sekolah disekolah mereka sebelumnya adalah guru kurang respek terhadap penanganan anak berkebutuhan khusus. Pendidikan yang diberikan kepada anak berkebutuhan khusus disamaratakan dengan anak normal lainnya. Karena guru menganggap bahwa anak berkebutuhan khusus butuh penanganan khusus yang seharusnya bukan disekolah inklusi melainkan di sekolah luar biasa. Tetapi setelah adanya pelatihan pelatihan lebih lanjut yang diberikan kepada para guru inklusi saat ini guru guru inklusi memberikan penanganan mengenai anak berkebutuhan khusus yang bersekolah disekolah inklusi dengan penanganan yang lebih bijak dalam bersikap dan memahami karakteristik anak berkebutuhan khusus. Hasil penelitian juga mengungkapkan sikap guru kelas terhadap anak berkebutuhan khusus sudah baik sesuai dengan pendapat Praptiningrum (2010) yang menyatakan bahwa seorang guru hendaknya memiliki 
optimisme terhadap pesertadidiknya. Guru hanya belum mencapai target maksimal dalam memahami karakteristik anak berkebutuhan khusus. Dalam pembelajaran yang diberikan juga sudah disesuaikan dengan kemampuan dasar anak berkebutuhan khusus dan juga guru memberikan remedial diluar jam sekolah untuk mengulang kembali pelajaran yang telah diajarkan tadi disekolah.

Hasil penelitian mengenai sikap guru terhadap anak berkebutuhan khusus berdasarkan menunjukkan kesesuaian dengan pendapat Santrock (2013) yang mengungkapkan bahwa guru idealnya memiliki kecederungan aktif dalam memberikan pendidikan bagi anak berkebutuhan khusus.

Hubungan yang baik juga harus dijalin antara guru dengan keluarga anak berkebutuhan khusus tersebut sehingga dalam proses belajar dirumah akan ada kesinambungan dan keberlanjutan antara pelajaran yang didapat dirumah dengan yang didapat disekolah. Hal ini sangat penting untuk meningkatkan proses pembelajaran anak berkebutuhan khusus sehingga guru tidak terlalu lama dalam mengajarkan kembali disekolah.

Proses pembelajaran di sekolah dapat berjalan dengan baik sangat dipengaruhi oleh peran guru dalam menghadapi peserta didik dengan baik hal ini sesuai dengan pendapat Suharsaputra (2011) dimana guru memiliki sikap tulus, peduli dan menerima siswa dengan baik. Namun, Guru belum sesuai kriteria berkaitan dengan pemenuhan hak kesetaraan terhadap anak berkebutuhan khusus. Sehingga peserta didik merasakan rasa nyaman untuk belajar didalam kelas. Begitu sama halnya dengan anak berkebutuhan khusus, mereka memiliki perasaan akan sikap yang ditunjukkan terutama oleh guru, teman dan lingkungannya dilingkungan mereka. Anak berkebutuhan khusus dapat merasakan sikap Penerimaan yang baik dan positif dari lingkungannya atau sebaliknya. Sikap penerimaan yang positif akan menumbuhkan semangat belajar anak berkebutuhan khusus didalam kelas.

Memiliki sikap yang tidak membeda-bedakan antara anak normal dengan anak berkebutuhan khusus haruslah dimiliki oleh semua guru dilingkungan sekolah inklusi. Karena hakikat dalam pendidikan semua orang berhak mendapatkan pendidikan yang layak. Dalam kenyataannya memang didalam dunia inklusi minimnya tenaga pengajar ataupun guru pendamping khusus yang mendampingi anak berkebutuhan khusus di sekolah inklusi. Hal ini berdampak terhadap sikap yang ditunjukkan guru saat mengajar anak berkebutuhan khusus di kelas. Anak berkebutuhan khusus yang seharusnya mendapatkan perhatian lebih malah lebih sering terabaikan karena guru tidak cukup memiliki waktu dan tenaga yang lebih untuk focus ke anak berkebutuhan khusus yang ada di sekolahnya.

Pada penelitian ini peneliti berfocus pada anak berkebutuhan khusus dengan inisial TM berusia 10 tahun, tetapi masih duduk dibangku kelas 1 SD Kebonsari 5. TM memiliki hambatan retardasi mental dan tuna laras. Sebelumnya peneliti sudah 
melakukan survey kerumah TM dan berbicara dengan nenek TM. TM dari lahir sampai usia 10 tahun tinggal bersama sang nenek dengan pola asuh nenek yang tidak paham tentang anak berkebutuhan khusus. Orang tua TM merantau ke Jakarta, menjenguk TM setahun sekali atau jika ada acara keluarga baru pulang kerumah. Kondisi yang demikian membuat TM kurang perhatian dan kasih sayang. Pada saat bersekolah di TK, TM pernah menjalani beberapa kali terapi untuk meminimalisir perilaku negatif yang membuat hilangnya konsetrasi saat belajar. Saat ini TM duduk dibangku SD kelas 1. Hal ini memberitahukan bahwa, kemampuan TM dalam hal akademik dibawah rata-rata dari teman seusianya. Dengan usia 10 tahun TM belum bisa membaca, menulis dan berhitung yang seharusnya sudah dikuasai oleh anak kelas 1 . Hal ini yang menyebabkan TM tidak naik kelas hingga 3x.

Disekolah TM sering mendapatkan nilai yang kurang baik dan sering melakukan tindakan yang kurang baik sehingga guru marah dan tidak menghiraukannya. Dalam satu kelas terdapat 35 murid dengan 1 guru, sehingga TM tidak mendapatkan perhatian khusus untuk bisa mengikuti pembelajaran dikelas. Beberapa guru sudah mulai memperhatikan dan memberikan penanganan khusus kepada TM, tetapi perilaku negative yang dimunculkan membuat guru tidak simpati dan akhirnya membiarkan TM.

Dalam hal ini, pemahaman guru terhadap anak berkebutuhan khusus kurang maksimal, guru memahami TM anak berkebutuhan khusus, tetapi dalam aplikasi sehari-hari guru mengecap TM adlh anak nakal yang sulit diberitahu. TM sering berlari lari dan juga TM sering keluar lari dari kelas, jika dikejar larinya akan semakin kencang. Hal ini juga yang membuat guru akhirnya membiarkan TM untuk mau belajar atau tidak didalam kelas. Berkaitan dengan proses belajar mengajar, guru mempunyai peranan yang penting. Guru memiliki tuntutan untuk mampu berperan dalam lingkungan masyarakat dan lingkungan sekolah secara profesional. Guru hendaknya memiliki tiga tingkat kualifikasi (Sardiman, 2012) meliputi capability personal, sebagai inovator, dan sebagai developer. Demi untuk mendapatkan hasil belajar yang optimal, Sardiman (2012) juga mengungkapkan adanya faktor lain yang mempengaruhi keberhasilan belajar siswa yakni berkaitan dengan hubungan antara guru dan siswa.

Sikap penerimaan guru yang baik akan membuat pembelajaran TM lebih mudah dikondisikan, TM akan memahami bahwa dimana saatnya dia belajar atau bermain. Kasih sayang yang ditunjukkan guru sangat mempengaruhi TM untuk diam dan mau mendengarkan apa yang disampaikan oleh guru. Namun ada beberapa guru yang sudah menilai buruk terhadap TM, sehingga dalam memperlakukan TM dalam proses pembelajaran kurang tepat seperti contoh membiarkan, memarahi, atau sampai main tangan. 
Peneliti mengamati saat proses pembelajaran bahwa disaat guru focus menjelaskan materi kepada seluruh siswa dikelas maka focus perhatian tidak bisa ke TM. Akhirnya TM sering keluar kelas. Peneliti juga telah melakukan wawancara terhadap beberapa guru mengenai TM saat pembelajaran. Sebagian besar guru mengemukaan bahwa sudah tidak bisa menangani TM dikelas sehingga guru membiarkan TM melakukan apa saja yang ingin dilakukan termasuk keluar kelas. Tetapi ada beberapa guru yang bisa meyakinkan TM untuk belajar didalam kelas seperti anak normal lainnya. Akhirnya peneliti melakukan pendekatan kepada TM, dan mengambil kesimpulan bahwa apa yang TM lakukan adalah bentuk dari ketidaknyamanan TM saat berada dikelas. Sehingga TM memutuskan untuk keluar dan tidak mau belajar bersama dengan guru tersebut.

Perlunya pelatihan-pelatihan khusus dan berkesinambungan untuk para guruguru di sekolah inklusi akan sangat membantu dalam hal proses penanganan anak berkebutuhan khusus disekolah masing-masing. Bagaimana sikap guru yang baik dalam proses pembelajaran, tindakan yang tepat untuk penanganan anak berkebutuhan khusus disekolah inklusi, dan bagaimana guru menyiasati proses pembelajaran agar anak berkebutuhan khusus merasa tertarik dan akan dengan senang mengikuti pembelajaran dikelas. Minimnya pelatihan kepada guru-guru sekoah inklusi akan berimbas pada kurangnya pemahaman guru akan hakekat anak berkebutuhan khusus itu sendiri, yang masih menganggap sama dengan anak normal tapi perilakunya negative (nakal) jadi perlakuan yang diberikan pun akan sama dengan anak normal. Jika anak normal dimarahin guru maka si anak dapat berfikir salahnya apa, tetapi tidak dengan anak berkebutuhan khusus, jika si guru marah maka yang ada dipikirannya adalah guru saya galak, sehingga ketika pelajaran anak berkebutuhan khusus tersebut akan melakukan kegiatan yang dia merasa akan aman dari sang guru.

TM merupakan gambaran dari salah satu anak berkebutuhan khusus yang bersekolah di sekolah inklusi yang mendapatkan perlakuan yang bereda dengan anak normal lainnya. Sehingga timbul perilaku negatif yang sebelumnya sudah ada makin bertambah, seharusnya bisa diminimalisir dengan proses pembelajaran dikelas.

\section{SIMPULAN}

Dari penerapan program pemerintah yaitu pendidikan inklusi untuk anak berkebutuhan khusus yang bisa sama-sama merasakan pendidikan di sekolah regular, sebaiknya benar-benar dipersiapkan untuk anak berkebutuhan khusus dapat belajar disekolah inklusi tersebut. Ketersediaannya pendidik yang cukup serta fasilitas pendidikan anak-anak berkebutuhan khusus sangatlah penting untuk mendukung proses belajar anak berkebutuhan khusus disekolah inklusi.Pemahaman akan hakekat anak berkebutuhan khusus terutama sangatlah penting untuk diketahui secara 
mendalam oleh guru-guru pendidikan di sekolah inklusi, karena akan sangat berhubungan dengan sikap penerimaan guru terhadap anak berkebutuhan khusus di sekolah inklusi tersebut. Sikap penerimaan yang baik dari guru akan berimbas positif juga terhadap perkembangan anak dikelas, peningkatan nilai akademik, tercipta sosialisasi dan komunikasi yang baik antara anak berkebutuhan khusus dengan teman sekelas dan dengan guru. Sehingga tujuan pembelajaran dapat terwujud sesuai dengan tujuan pendidikan inklusi.

\section{DAFTAR PUSTAKA}

Arikunto, S. (2002). Prosedur Penelitian. Jakarta : PT. RinekaCipta

Mc. Leskey, James, Michael S. Rosenberg \& David L. Westling. (2013). Inclusion: effective practice for all students. Edisi 2. New Jersey: Pearson Education.

Mustofa, A. (2017). Sikap Guru Kelas Terhadap Anak Berkebutuhan Khusus Disekolah Dasar Inklusi Wilayah Kabupaten Magelang. Jurnal Widia Ortodidaktika, 6(3):280-290.

Praptinigrum, N. (2010). Fenomena Penyelenggaraan Pendidikan Inklusif bagi Anak Berkebutuhan Khusus. Jurnal Pendidikan Khusus, 7(2);32-39.

Santrock, John W. (2013). Psikologi Pendidikan. Edisi 2. Penerjemah: Tri Wibowo B.S. Jakarta: Kencana Prenada Media Group.

Sardiman A. M. (2012). Interaksi dan Motivasi belajar Mengajar. Jakarta: Raja Grafindo Persada.

Uhar, S. (2011). Menjadi Guru Berkarakter. Sleman: Paramitra Publishing. 